\title{
Morpho-functional elements in the miniature genre Chastushki, from the folklore of the Lipovan Russians
}

\author{
Mirela KOZLOVSKY ${ }^{1}$
}

\begin{abstract}
The Lipovan Russians have been settling on Dobrogea for more than three hundred years, especially in the villages of the Danube Delta. Due to the isolation provided by the surrounding waters, they have managed to preserve and transmit language, religion, culture and way of life from generation to generation. The existing musical repertoire in community practice is rich and varied. The traditional creations that are found in most musical genres belong to both the old and the new layer of creation. The present study aims to highlight the morpho-functional elements of a miniature genre - Chastushki - which can be performed exclusively vocally or with instrumental accompaniment. Chastushki, a musical genre based on improvisation, is specific to traditional Russian culture and was brought from the territories of origin by Lipovan Russians from Dobrogea. This genus is currently threatened with extinction.
\end{abstract}

Key-words: ethnomusicology, Chastushki, musical-poetic species, improvisation, folklore, Lipovan Russians.

\section{Introduction}

The present study is the result of field research that we conducted in Constanța and Tulcea counties, in localities inhabited by Lipovan Russians. I wanted to highlight the morpho-functional aspects of Chastushki, a small musical genre that is found in the folklore of the Lipovan Russians from Dobrogea. These researches took place in the period 2018-2019, and we used observation and interview as the

1 “Ovidius” University of Constanţa, Faculty of Arts, mirelakoz@gmail.com 
main methods of investigation, and the information obtained was recorded digitally (audio, photo and video).

We started from the hypothesis that, only by knowing the morpho-functional aspects of a traditional musical genre threatened with extinction, we can contribute to its salvation and maintenance in the community repertoire. The main purpose of this study is to valorization on the cultural heritage of the Lipovan Russians from Dobrogea, providing those interested with accurate and complete information, collected and scientifically transcribed. At the end of the scientific approach, we aimed to make the most efficient use of the information obtained with reference to the miniature genre from the musical repertoire present in the practice of the Lipovan Russians, because its characteristics have been amazingly well preserved.

The disruptive factor that threatens in the future the passage of this genre in the passive memory of the ethnic group or that can determine its disappearance is the decrease in the number of community creators due to the lack of public interest. In order to prevent such situations, we have the duty to collect and valorize from a scientific point of view the musical repertoire of the Lipovan Dobrogean Russians, offering in the future the chance to those interested to know and appreciate it at its true value.

\section{Ethnocultural landmarks of the Lipovan Russians from Dobrogea}

The Lipovan Russians, together with other ethnic groups from the Dobrogea area, represent a special community through its distinct, Slavic culture. They migrated en masse from their territories of origin in the second half of the seventeenth century, when, at the initiative of Tsar Alexei Mikhailovsky and Patriarch Nikon, new reforms were introduced in the Russian Church to replace old books and church arrangements with those of origin. Greek (Tudose 2015, 12).

Also during this period, in the Russian Church there is a split that materialized through the emergence of a religious community in Orthodox society the old rite believers (staroverii) (Tudose 2015, 12). Dissatisfied with the reforms imposed by the patriarch, the starovers will migrate massively and will have to adapt to harsh conditions, sometimes hostile in territories far from those of origin. It is estimated that there are more than three million old rite believers who have left their home territories (Ipatiov 2001, 29). Starovers spread to Poland, Moldova or the Ottoman Empire, Bugeac and Dobrogea. 
The Russian ethnonym Lipovean, which essentially hides the main "characteristics" of its wearers - nationality and religious affiliation, still generates an ambiguous attitude among starovers and the issue of the origin of this name is still controversial.

According to one of the hypotheses, dating from the end of the 18th century, the name Lipovean is considered as a derivative of the Slavic word lipa, which in translation means linden. It is claimed that the starover Russians who arrived in our country initially settled near a linden forest, in order to be protected from possible dangers, and to have at hand the wood needed to build houses and make utensils, painted icons and of home furniture (Abakumova-Zabunova 2013, 86).

Those who settled in the Dobrogean lands, which at that time were under the rule of the Ottoman Empire, did not have limited faith and were allowed to live in accordance with the traditions and main occupations. Because they came from the area of the Dnieper, Volga and Don rivers, the Lipovan Russians were still able to practice their favorite profession, that of fishermen (Tiuliumeanu 2015, 121).

In the past, Lipovan men were distinguished by their long beards, which they wore as a sign of faith and closeness to God. (Râşnoveanu 2008, 255) Men do not shave their beards because in the old-rite Christian-Orthodox faith this is considered a great sin. Currently, most Lipovan Russian men, especially after retirement, let their beards grow.

The Lipovan Russians are old-rite Orthodox Christians (staroveri), who have kept their religion unchanged since 988 (the period of Christian Russia in Kiev by Prince Vladimir Sveatoslavici). The term Lipovean is found mainly in the inhabitants of southern Ukraine and in the Romanian province of Dobrogea, and clarifies the ethno-confessional status of the wearer (Abakumova-Zabunova 2013, 86).

From a religious point of view, in Dobrogea there are three branches of believers. The first refers to the Lipovan Russians called popovtî (those with a priest), bezpopovtî (without priests) and beglopopovtî (those with an occasional priest) (Jora 2014, 55). Religious services are celebrated in the Slavonic language, and the calendar used by the community is the Julian one.

Worship objects are assigned a special role, being valued and present in the life of Lipovan Russians at home, in the church and on the body (the pois is a belt received at baptism and worn by ethnic groups throughout life). From those interviewed we learned that there are old books and icons from the seventeenth century, considered invaluable objects, brought by the first exiles from Russia. 
Starover dwellings abound with symbols of faith, so that from the entrance, above the door, on the east wall is placed an icon or a crucifix. These icons are consecrated at the church by the priest and give the real feeling of the presence of God or the saint represented in the icon. Through them, the Lipovan Russians contemplate the Kingdom of God and enter into a direct dialogue with the divinity. In many families there are precious icons, both by their antiquity - two, three hundred years, and by the fame of the craftsman who painted them. Having an essential role in the community, the icon is indispensable in the nuptial and funeral rituals.

Lipovan Russians are trilingual, speaking Romanian in the relationships imposed by society (school, work, etc.), Russian in the family or in the community and Slavonic ${ }^{2}$ in church and religious ritual.

It is well known that these ethnic groups lead a simple, modest and free life. Men are said to be very good at boats, fishing and sailing. And women are famous housewives both for the prepared dishes and for their skill in creating meticulous embroidery (linen, mile, curtains, etc.).

In the homes of Lipovan Russians there is lejanka, a terracotta stove that provides heat. Built like a terracotta bed, this stove is an ideal place to sleep, especially in winter, when the frost is severe. In the past, fishermen with cold and wet clothes could not wait to get home, change their clothes, sleep on the lejanka and benefit from the therapeutic effects of the heat released by the terracotta tiles.

We must also mention the Russian bath, called bania and similar to the sauna. Unique in the Carpatho-Danubian cultural space, it demonstrates the concern of Lipovan Russians for the cleanliness of their own body and self-care.

The ethnic Lipovan Russians are pleasant in appearance. Men have a solid build, white faces, brown hair and light eyes. The women are of medium height, usually blonde and with blue eyes. They are cheerful, hardworking and good housewives. Until recently, Lipovan Russians wore traditional clothes both in everyday life and at church. Currently, the traditional costume is worn in church activities and in the cultural-artistic manifestations of the communities (Tudose 2015, 176).

The traditions and customs of the Lipovan Russians from Dobrogea are closely related to the religious holidays and important events in human life. These have been preserved and perpetuated from generation to generation within the

2 acc. DEX Slavonic is the Church and literary Slavic language that developed in Russia, Serbia and Bulgaria from the old Church Slavonic (of the writings of Methodius and Cyril); church language of the southern Slavs from the sec. IX. 
family and the community. Those considered anachronistic have been abandoned and others have been "adapted" to suit modern lifestyles and thinking.

Currently, the emergence of technology and adaptation to allogeneic or disinterested environments from a social and cultural point of view (permanent or temporary establishment in another country), marriages to persons outside the community, etc. are factors that have produced a slight "relaxation" in the patriarchal lifestyle of the Lipovan Russians.

Despite these changes, the family and the priest are two more concepts that play an important role in the daily lives of these ethnic groups. The family remains the most important structure for preserving social identity, being the framework in which children integrate into the ethnic group to which they belong and the priest, by organizing activities to learn the Slavonic language and religious songs, contributes to the expansion of the church and affirmation youth belonging to the community.

\section{Traditional music repertoire}

The Lipovan Russians are part of a persevering and tenacious people, who has harnessed his creative sensibility by conceiving valuable cultural goods, able to offer them identity recognition in the amalgamated environment of Dobrogea.

The musical repertoire has been transmitted over time exclusively orally. Regardless of age, the community reproduces the songs from memory, without significant deviations from the melodic line. The main factor that contributed both to the memorization and to the transmission of the songs is the participation of the whole group (families or community) in the holidays and community events.

The most resistant musical genre in the folklore of the Lipovan Russians is that of the song per se. The lyrical songs predominate, the songs managing to reproduce feelings such as love, longing, fear of the unknown and hope for the best. The interpretation of this genre can be univocal or in two voices, the main melodic line being accompanied by another melody at third intervals, sometimes fourth, fifth and perfect octave. The performers, in the desire to synchronize and avoid deviations from the established model (unanimously accepted and known by community members), currently prefer melodic lines without ornamental notes and with a giusto-syllabic rhythm. The main characteristic of the sound systems present in the musical repertoire consists in their diatonism. 
Cheerful, optimistic and sincere people, the Lipovan Russians have many happy songs in their repertoire. They are structured on the stanza-chorus pattern and take place in a lively tempo. The lyrics of the songs bring to the listener's attention stories or comic characters, all ending with moralizing and optimistic conclusions.

The Lipovan Russians did not practice folk dance in the community, and that is why the melody of some actual songs serve as dance songs. The explanation is related to the religious dogma that forbids starovers, like other Orthodox Christians, to manifest themselves through dance. Only ritual dances were allowed. The lack of playing music is also due to the fact that there were no instruments to promote such a genre. With the advent of harmonika instrumentalists (harmoșca - in dialect), an accordion-like instrument, dance music was born (Bărbuceanu 1999, 9).

For many generations the music practiced was vocal. At the various parties in the community, women and men sang a rich and varied repertoire. The vigor, the natural joy, the temperament and the dynamism of the interpretation represent the main qualities that allowed the integration of the songs in the sphere of the popular dance.

Currently, dance music is considered a cultural asset of the community, the Lipovan Russians identifying with this repertoire, which they valorize on stage at various cultural events.

The lullaby can be found in the community repertoire. For the Lipovan Russians from Dobrogea this genre belongs to the improvisational style. In the process of creation, the mother uses melodic-rhythmic formulas existing in the ancient practice of this people, as old as the rocking movement of the baby.

The Lipovan Russians do not have the carol in their repertoire, therefore, in order to make up for the lack of specific creations, the integration of the religious song Hristos rajdaetsja!/ Christ is born! took place in the community practice in the kind of carol. In the Lipovan villages from Dobrogea there are several variants, with changes to the text, the melodic line and the interpretive style.

\section{Chastushki / частушки or "shouts" sung}

The character of the Lipovan Russians, their love of life and their remarkable determination in solving everyday problems and difficulties, revealed small folk 
songs in which the lyrics are usually a response of community members to a topical event or a existing problem situation.

Chastushki is translated by often and frequently. It is a small musical genre, through which the popular creator transmits a current news, a certain novelty, in order to amuse the listeners, to determine them to participate - in a word, to arouse their interest and make them be witnesses to something. In this genre music is subordinated to the text, and therefore the melodic line is simple and easy to remember. The rhythm is giusto-syllabic, trochaic (the accent is on the first syllable of the word) and the pattern of the lyrics is octosyllabic. The sound systems are diatonic, and the architectural form, fixed, is simple. Chastushki is created for public performance and loses its real meaning outside of such a performance. Most of the time the message sent is humorous and is direct, real, depending on the beneficiary and its specific content. This leads us to say that the members of the community knew each other very well, so that the defects, the flaws or the intimate feelings were not a secret for the creators and the public.

Even chastushki with lyrical texts, which mirror the love for the loved one or less favorable personal experiences, are full of humor, which demonstrates the optimistic view of the Lipovan Russians on life. The longevity of this genre depends mainly on the relevance of the content of its text.

These songs are heard at community holidays and weddings, and therefore, of great importance in the composition of the lyrics is the reason for organizing the holiday, the age and preferences of those present.

With the evolution of society, other rules are applied in the relations between communities, and the popular creator is attracted to new themes, ideas and images, which offer a new perspective on life. However, chastuski, short songs with humorous content, remain relevant. They stand out for their originality, reflecting the popular creator's reaction to events in the community or in personal life (Drumea, Zaicovschi 2013, 55).

It is a genre built on improvisation based on stable melodic formulas, with concise melodic line, with ornamented sounds and variations of rhythms. Chastushki are performed vocally, with a predilection by women, and sometimes the singer's voice can be accompanied by the harmonika.

They are anonymous and accessible creations, which can be taken over and continued by other people with improvisational talent who, keeping the melodic line, can modify the text depending on the desired subject. Due to the 
concentration of the text, the stanzas from chastushki follow one another according to a certain theme, so that the performers compete in composing the most remarkable lyrics. The participants in the party are not just simple listeners, they can intervene with their own lyrics in the unfolding of the artistic moment. The main condition that must be taken into account is the maintenance of the cross rhyme. Sometimes, those present dance, clap, comment, object or backing the performer. These manifestations take place during the instrumental interlude or chorus, if any. The chorus in chastushki is composed from a literary point of view of syllables or interjections, interpreted in accordance with the atmosphere released by the text of the melodic stanzas (Oprea 2002, 141).

Created in verse or prose, chastushki is structured on the stanza-chorus scheme and is performed in an alert tempo. A characteristic feature is the quantitative coincidence of the verse and the melodic line, which intertwine in order to express the same content. The expressiveness and richness of linguistic means often go beyond literary language. In addition to interjections and puns, the most common compositional procedures encountered in this genre are verse repetition, analogical and explanatory parallelism.

Using an ironic, sarcastic language, sometimes lacking in decency, chastushki can be included aesthetically in the realm of the comic. Even if in these songs the moral defects of the people or the negative aspects of the society are criticized, the purpose is moralizing or educational.

I chose for the presentation chastushki "Ох ты миленький ты мой” / "Ah, my dear", performed vocally by Mrs. Irina Mihailovici from Slava Cercheză commune. 

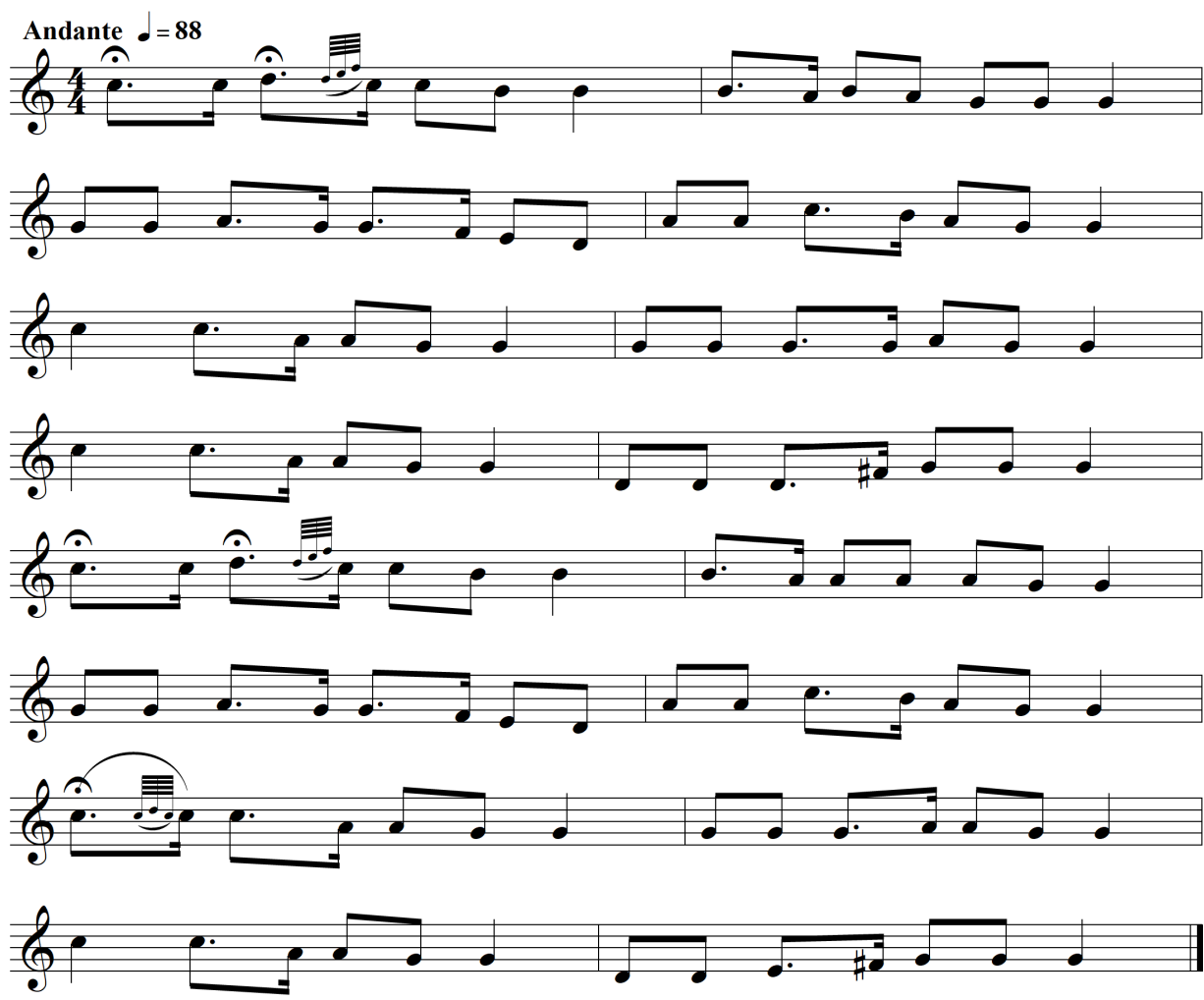

Ох ты миленький ты мой / Ah, my dear

Ох ты миленький ты мой

Ох ты миленький ты мой,

бей об камень головой

Аж тогда тебя поверю что ты думаешь за мной.

Меня милый не целует и за великого поста

А любовь без поцелуя, как корова без хвоста.

Меня милый не целует, ой какой он молодец

Он свои большие губы бережот на холодец

Bот из леса выезжает конная милиция

Становитесь девки раком будет репетиция 
Ох ты миленький ты мой, бей об камень головой Аж тогда тебя поверю что ты думаешь за мной

Сорок лет, бабе век, шестьдесят сносу нет А вернётся сорок пять, баба ягода опять

Ah, my dear,

Ah, my dear,

if you bump your head into the stone

I'll know what you think of me.

My dear, don't kiss me, it's Lent,

And love without a kiss is like a cow without a tail.

My dear does not kiss me, ah, what courage he has.

Soft lips and keeps them, For a good meatball.

The militia emerges from the forest on horseback,

And lay the girls on the ground, for repetition.

Ah, my dear, if you bump your head into the stone

I'll know what you think of me.

At forty, it's a woman's time, at sixty she is withered,

And at forty-five, she's really good again.

\section{Conclusions}

The analysis of this musical genre revealed the following morpho-functional elements:

- $\quad$ Tempo: Andante, with a quarter at 88 M.M .;

- Lyrics pattern: octosyllabic;

- Versification: syllabic type;

- Rhythm: giusto-syllabic;

- The musical scale: major mode on Do (do1,re1, mi1, fa1, sol1, la1, si1, do2);

- $\quad$ The form of the melodic stanza: fixed, simple, ternary ABCCv;

- Ambitus: a major ninth, of the type do1-re2, defines the structure of the melody; 
- The musical line profile: sinuous;

- Sounds with functions: the sounds do2, la1, sol1 sound pillars; the sounds la1, sol1 and re1 recitation chord; the re2 sound represents the climax of the song (the highest sound); fa1 sound which is heard twice, in a double sound hypostasisis fa1 and fa\#1, consolidates the sol 1 note, who is playing the role of the final note;

- Inner cadences: on the fifth step by repetition;

- Final cadence: on the fifth step by repetition.

The musical repertoire of the Lipovan Russians from Dobrogea kept these miniature songs due to the conciseness, the alert tempo, the moralizing role and the optimistic character in solving the unusual situations that the lyrics signal. This kind of song has withstood the test of time because it has kept pace with the everincreasing pace of society's evolution, managing to fit into this way of life, being, in fact, a spontaneous creation that does not take the listener much long time. Despite the brevity, chastushki is distinguished by its rich poetic language.

In community practice, these creations contribute to the connection between individuals, between families and, in general, contribute to the solidarity of the community.

In the age of globalization, the intangible cultural heritage of the Lipovan Russian communities is a true identity mark, so necessary in a territory with a heterogeneous population, such as Dobrogea. Even though they are well represented numerically and isolated from the Delta, in the Lipovan Russians from Dobrogea also some customs, traditions and musical genres have suffered contaminations or have disappeared from the community practice.

We want this study to be useful for future efforts in terms of research and valorization of the musical repertoire, and also to be an impetus for the preservation and transmission of traditional culture.

\section{References}

Abakumova-Zabunova, Natalia. 2013. "Referințe la exonimele și endonimele rușilor-lipoveni din Moldova. [References to the exonyms and endonyms of the Russian-Lipovans from Moldova]." Journal of Ethnology and Culturology vol. XIII-XIV: 86-95. Chisinau. Academy of Sciences of the Republic of Moldova 
Bărbuceanu, Valeriu. 1999. Dicționar de instrumente muzicale [Dictionary of Musical Instruments]. Bucharest. Teora publishing house.

Drumea, Luminiţa and Tatiana Zaicovschi. 2013. "Componenta feminină a mentalității ruse și reflectarea ei în folclorul rus din Republica Moldova. [The female component of the Russian mentality and its reflection in Russian folklore in the Republic of Moldova]." Journal of Ethnology and Culturology vol. XIII-XIV: 50-58. Chisinau. Academy of Sciences of the Republic of Moldova

Ipatiov, Filip. 2001. Rușii lipoveni din România. Studiu de geografie umană [The Lipovan Russians of Romania. A Study in Human Geography]. Cluj-Napoca. Presa Universitară Clujeană publishing house.

Jora, Roman. 2014. Folclor muzical-coregrafic al rușilor lipoveni din Județul Tulcea

[Musical and Choreographic Folklore of the Lipovan Russians of Tulcea County]. Constanța. Ex Ponto publishing house.

Oprea, Gheorghe. 2002. Folclorul muzical românesc [Romanian Musical Folklore]. Bucharest: Editura Muzicală publishing house.

Râșnoveanu, Ion. 2008. "Aspecte privind minoritățile etnice și religioase din Dobrogea interbelică" [Aspects regarding the Ethnic and Religious Minorities of Interwar Dobrogea]. In Dobrogea - model de conviețuire multietnică și multiculturală [Dobrogea - a Good Example of Multi-ethnic and Multicultural Cohabitation], coord. by V. Coman, 251-263. Constanța: Muntenia publishing house.

Tiuliumeanu, Mihai. 2015. Cazacii din Dobrogea: o istorie uitată [The Cossacks of Dobrogea: a Forgotten Piece of History]. Bucharest. Published by Editura Militară.

Tudose, Pavel. 2015. Rușii lipoveni din România - istorie și actualitate [The Lipovan Russians of Romania - History and Current Situation]. Bucharest. Published by Comunitatea Rușilor Lipoveni din România. 